\title{
ASSOCIATION BETWEEN HUMAN PAPILLOMAVIRUS AND COLORECTAL ADENOCARCINOMA AND ITS INFLUENCE ON TUMOR STAGING AND DEGREE OF CELL DIFFERENTIATION
}

Associação do Papilomavírus humano com o adenocarcinoma colorretal e sua influência no estadio tumoral e no grau de diferenciação celular

Olavo Magalhães PICANÇO-JUNIOR ${ }^{1}$, Andre Luiz Torres OLIVEIRA ${ }^{3}$, LuciaThereza Mascarenhas FREIRE ${ }^{3}$, Rosangela Baia BRITO², Luisa Lina VILLA ${ }^{1}$, Délcio MATOS ${ }^{1}$

From the ${ }^{1}$ Programa de Pós-graduação em Gastroenterologia Cirúrgica, Escola Paulista de Medicina, Universidade Federal de São Paulo - UNIFESP, São Paulo, SP; ${ }^{2}$ Hospital Ophyr Loiola, Belém, PA; and ${ }^{3}$ Instituto Ludwig de Pesquisa sobre o Câncer do Hospital Alemão Oswaldo Cruz ('Postgraduate Program of the Federal University of São Paulo (UNIFESP), São Paulo, SP; ${ }^{2}$ Ophyr Loiola Hospital, Belém, $\mathrm{PA}$, and ${ }^{3}$ Ludwig Cancer Research Institute at the Oswaldo Cruz German Hospital, São Paulo, SP), Brazil

HEADINGS - Papillomavirus infections.
Carcinoma. Colorectal neoplasms. Neoplasm saging. Cell differentiation.
ABSTRACT - Background: Colorectal cancer is one of the most common types of neoplasia among the worldwide adult population. Among neoplasms of the gastrointestinal tract, it is ranked second in relation to prevalence and mortality, but its etiology is only known in around $5 \%$ of the cases. It is believed that $15 \%$ of malignant diseases are related to viral oncogenesis. Aim: To correlate the presence of HPV with the staging and degree of cell differentiation among patients with colorectal adenocarcinoma. Methods: A retrospective case-control study was conducted on 144 patients divided between a test group of 79 cases of colorectal cancer and a control group to analyze 144 patients aged 25 to 85 years (mean, 57.85 years; standard deviation, 15.27 years and median, 58 years). Eighty-six patients (59.7\%) were male. For both groups, tissue samples from paraffin blocks were subjected to DNA extraction followed by the polymerase chain reaction using generic and specific primers for HPV 16 and 18. Dot blot hybridization was also performed with the aim of identifying HPV DNA. Results: The groups were shown to be homogenous regarding sex, age and site of HPV findings in the samples analyzed. Out of the 41 patients with HPV, $36(45.6 \%)$ were in the cases and five $(7.7 \%)$ were in the control group $(p<0.001)$. All the HPV cases observed comprised HPV 16, and HPV 18 was not shown in any of the cases studied. There were no significant differences in comparisons of sex, age and site regarding the presence of HPV in either of the groups. It was not observe any significant difference in relation to staging or degree of cell differentiation among the patients with colorectal cancer. Conclusion: Human papillomavirus type 16 is present in individuals with colorectal carcinoma. However, its presence was unrelated to staging or degree of differentiation.

\section{Correspondence:}

Olavo Magalhães Picanço-Junior

Email: olavopicanco@unifap.br

Financial source: none

Conflicts of interest: none

Received for publication: 20/02/2014 Accepted for publication: 08/05/2014
DESCRTIORES - Infecções por papilomavírus. Carcinoma. Neoplasias colorretais. Estadiamento de neoplasias. Diferenciação celular.
RESUMO - Racional: O câncer colorretal é uma das neoplasias mais frequentes entre a população adulta mundial, e entre as do trato gastrointestinal, é a segunda em relação à prevalência e mortalidade sendo a sua causa conhecida apenas em cerca de $5 \%$ dos casos. Acredita-se que $15 \%$ das doenças malignas estariam relacionadas à oncogênese viral. Objetivo: Correlacionar a presença do HPV com o estadiamento e o grau de diferenciação celular dos pacientes portadores de adenocarcinoma colorretal. Métodos: Foi realizado um estudo retrospectivo do tipo casocontrole com 144 pacientes divididos em um grupo teste representado por pacientes com câncer colorretal em um total de 79 casos e um grupo controle correspondente à pacientes com doença benigna totalizando 65 casos. Após a aplicação dos critérios de exclusão, foi possível analisar 144 pacientes com idade entre 25 a 85 anos (média de 57,85 anos com desvio-padrão de 15,27 anos e mediana de 58 anos). Oitenta e seis (59,7\%) pacientes eram homens. Amostras teciduais a partir de blocos de parafina de ambos os grupos foram submetidos à extração do DNA e em seguida foi realizada reação em cadeia da polimerase com iniciadores genéricos e específicos para HPV 16 e 18 e também a hibridização do tipo dot blot com o intuito de identificar o DNA do HPV. Resultados: Os grupos se mostraram homogêneos quanto a sexo, idade e localização do HPV nas amostras analisadas. Dos 41 pacientes com HPV, 36 (45,6\%) eram do grupo teste e cinco $(7,7 \%)$ do grupo controle $(p<0,001)$. Todos os casos de HPV observados correspondiam ao HPV 16 não sendo evidenciado HPV 18 em nenhum caso estudado. Não houve diferença significativa na comparação realizada quando se considerou o sexo, idade e localização no que tange a presença do HPV em ambos os grupos. Não observou-se diferença significativa em relação ao estádio e ao grau de diferenciação celular dos pacientes portadores de câncer colorretal. Conclusão: O papilomavírus humano tipo 16 está presente em indivíduos portadores de carcinoma colorretal. No entanto, não está relacionado com o estadiamento e o grau de diferenciação.

INTRODUCTION

C olorectal cancer is a multifactorial disease and can be studied from its earliest to the most advanced forms, making possible to understand the mechanisms that could be involved in its development. It can be highlighted the multiple genetic steps related to the carcinogenesis process ${ }^{28}$.

There is evidence that dietary and environmental factors play an important role in the development of colorectal cancer ${ }^{19}$. According to Giuliani ${ }^{7}$, several factors could be involved in colorectal carcinogenesis including factors relating to lifestyle, sequential genetic alterations and viral infection.

The human papillomavirus (HPV) is the cause of one of the most prevalent sexually transmitted diseases in the world, and there are studies in the medical literature that 
correlate it with the development of adenocarcinoma in the colon $23,5,18$. However, it is most commonly related to the development of cancer of the anal canal $3,12,24$ and especially the uterine cervix ${ }^{15,16,21,26,27}$

Because of these data and the already confirmed carcinogenic potential of HPV in the cervix and anal canal, detection and identification of papillomavirus as a predisposing factor for colorectal carcinogenesis is necessary. This may allow identification of risk groups and assist in the development of new therapies based on understanding the biology of this disease ${ }^{18}$.

Based on the findings in the literature, these authors were motivated to conduct this study to search for a possible association between HPV and colorectal adenocarcinoma, along with the possibility of a relationship with prognostic factors for this disease, such as the patients' degree of cell differentiation and stage.

\section{METHODS}

This study was reviewed and approved by the Research Ethics Committee of the Federal University of São Paulo, São Paulo, Brazil, under number 1377/08. This was a case-control study, conducted in partnership with the Ophyr Loyola Hospital and Ludwig Cancer Research Institute.

\section{Patients}

A total of 182 patients were initially selected for the study from January 1999 to December 2003. After applying the inclusion and exclusion criteria, the remaining patients were divided into two groups: 79 cases in the test group (TG) and 65 cases in the control group (CG). The inclusion criteria were that the patients needed to have been admitted to the Ophyr Loiola Hospital, Belém, PA, Brazil, for treatment and diagnostic investigation according to the group to which they were allocated, classified in accordance with the TNM system, with medical records and paraffin blocks representing the primary tumor, filed in the Department of Pathology, as well as blocks from the patients who only underwent a biopsy.

In cases in which it was not possible to obtain viable DNA for PCR, the patients were excluded. There were three such cases in the TG and 12 in the CG. Another five cases in the CG were excluded because they were diagnosed as adenomas. Patients who had undergone prior radiotherapy were also excluded.

Regarding the descriptive data, the patients comprised 40.3\% females and $59.7 \%$ males. Most cases were beyond their $5^{\text {th }}$ decade $(67.2 \%)$ and according to the location, $53.5 \%$ of lesions were located in the rectum. The distribution according to clinical stage consisted of 10 cases in stage I (12.7\%), 27 cases in stage II (34.2\%), 26 cases in stage III (32.9\%) and 16 cases in stage IV (20.3\%). All cases in the TG comprised samples from patients with colorectal adenocarcinoma. The CG consisted of one case of normal mucosa $(0.7 \%)$, 35 cases of inflammatory lesion of the mucosa (24.3\%), 28 cases of mucosal polypoid lesion (19.4\%) and one case of hypoganglionosis $(0.7 \%)$.

\section{Histopathological diagnosis}

After data collection, the tissue samples were immediately immersed in a buffered solution of $10 \%$ formaldehyde to preserve the material and were sent to the Pathology Division of the Ophyr Loyola Hospital. In this sector, the formalin-fixed specimens were embedded in paraffin and processed using standard histopathological techniques. The diagnostic evaluation was performed by pathologists of the institution and samples from the patients who fulfilled the criteria for the TG and CG were selected for the study.

After this selection, the paraffin blocks containing genetic material from the selected cases were sectioned and sent in sterile tubes to the Ludwig Cancer Research Institute in São Paulo for the polymerase chain reaction (PCR) to be performed.

\section{DNA extraction and PCR}

Sections of paraffin-embedded tissues deposited in a tube were subjected to the deparaffinization process and enzymatic digestion with proteinase $\mathrm{K}(200 \mathrm{mg} / \mathrm{ml})$ at $56{ }^{\circ} \mathrm{C}$ for 2-4 days. After digestion, DNA was extracted using the phenol-chloroform method recommended by Sambrook ${ }^{22}$.

After extraction and purification, the DNA samples were subjected to PCR, using the primers PCO3 and G74 (oligonucleotide primers used in PCR amplification reactions), which amplify 100 base pairs (bp) of the human b-globin gene ${ }^{1}$, with the aim of evaluating the adequacy and integrity of the DNA present in each sample.

The positive samples were subjected to PCR with generic primers for HPV $\left(\mathrm{GP} 5+/ \mathrm{GP} 6+{ }^{8}\right)$, capable of amplifying $140 \mathrm{bp}$ of the HPV L1 gene.

To demonstrate that there was no contamination by exogenous DNA, a negative control was used, containing all the reagents of the mixture except for the DNA. A lineage of HeLa cells containing DNA from integrated HPV $18^{26}$ was used as the positive control.

The amplifications were performed in an Eppendorf thermocycler, Mastercycle gradient (Germany). Forty cycles of amplification were effected applying $1 \mathrm{~min}$ for denaturation at $95^{\circ} \mathrm{C}, 1 \mathrm{~min}$ for annealing at $55^{\circ} \mathrm{C}$ and $1.5 \mathrm{~min}$ for the chain elongation at $72^{\circ} \mathrm{C}$.

The amplification products, also known as amplicons, were analyzed on $7 \%$ polyacrylamide gel stained with silver.

Identification of HPV by means of dot blot hybridization (Dot Blot)

This method is based on the general principles of hybridization, in which the amplified product is denatured and fixed through stitches onto a nylon membrane. The procedures for fixation of the amplicon onto the membrane include heating or UV irradiation. Then the membrane is coated with specific probes (singly or as cocktails) for HPV types $6,11,16,18,31,33,34,35,39,40,42,43,44,45,51,52$, 54,56 and 58, labeled with radioactive phosphorus (P32). The hybridization is revealed after exposure of the membranes to X-ray film for 18 to $36 \mathrm{~h}$ at $70^{\circ} \mathrm{C}$. Hybridization with the probe is recognized as evidence that the nucleotide sequence searched for is present in the specimen.

It was used in each membrane, in addition to positive and negative controls for the PCR products, controls for different types of HPV, from PCR amplifications of clinical samples and plasmids.

After this, the membranes were wetted with 2xSSC solution and placed in a plastic bag with $5 \mathrm{ml}$ of 6 xSSC solution, 10x Denhardt's, 0.5\% SDS and $100 \mathrm{mg}$ of denatured salmon sperm, and then were incubated at $55^{\circ} \mathrm{C}$ for three hours (pre-hybridization).

Then, radioactive probes were added to the above solution, which was left to continue incubating at the same temperature for 12 to $24 \mathrm{~h}$ (hybridization). At the end of this period, the membranes were washed with 3xSSC solution and $0.5 \%$ SDS in three stages: the first for $10 \mathrm{~min}$ at room temperature; the other two for 30 min each at $55^{\circ} \mathrm{C}$. Finally, the membranes were exposed to $\mathrm{X}$-ray film (X-OmatK-Kodak) for 18 to $36 \mathrm{~h}$ at $-70^{\circ} \mathrm{C}$. The hybridization was observed after the film was developed, through the presence of dark spots at the location corresponding to the samples that were added to the membrane.

Specific PCR for E7 of HPV 16 and 18

The samples were used in a PCR with specific primers for E7 of HPV 16 and 18, with the capacity to amplify 217 
bp for E7 of HPV 16 and 137 bp for E7 of HPV 18. Regarding specific primers for HPV 16, the following were used: $5^{\prime}$ GCC CAT TAA CAG GTC TTC C 3'; 5' TTT GCA ACC AGA GAC AAC TGA 3’. For HPV 18: 5’ ATG TCA CGA GCA ATT AAG C 3’; 5’ TTC TGG CTT CAC ACT TCA AAC A 3'.

The amplifications were performed in an Eppendorf thermocycler, Mastercycle gradient model (Germany). Forty cycles of amplification were effected, applying 1 min for denaturation at $95^{\circ} \mathrm{C}, 1 \mathrm{~min}$ annealing at $55^{\circ} \mathrm{C}$ and $1.5 \mathrm{~min}$ for the chain elongation at $72^{\circ} \mathrm{C}$.

The amplification products, also known as amplicons, were analyzed on $7 \%$ polyacrylamide gel stained with silver, analyzed in a way similar to what was done using generic PCR.

\section{Statistical analysis}

The results were initially subjected to descriptive analysis on all the variables. For the quantitative variables, this analysis was done by observing the minimum and maximum values and calculating means, standard deviations and medians. For the qualitative variables, the absolute and relative frequencies were calculated. To test the homogeneity between the proportions, the chi-square test was used, or the Fisher exact test when the expected frequencies were less than five.

The significance level for rejecting the hypothesis of nullity among the samples analyzed was established as $5 \%$.

\section{RESULTS}

While developing this study, three cases were excluded from the TG due to negative results from the human $\beta$ globin gene test for identification of viable DNA. Likewise, in the CG, it was necessary to exclude eight cases. Another five cases were excluded because they referred to adenomas, and thus the total number in the CG was 65 cases. Seventy-nine cases in the TG showed positivity for the human $\beta$ globin gene (92.9\% the samples).

After applying the exclusion criteria, were analyzed 144 patients aged 25-85 years (mean of 57.85 years, with a standard deviation of 15.27 years, and median of 58 years). Eighty-six patients (59.7\%) were male.

HPV was found to be present in 41 patients, representing $28.5 \%$ of the total number of cases, being only identified the presence of HPV 16 in all the cases, and even using hybridization and PCR specific for HPV 18, this was not found in any of the cases.

Seventy-nine patients (54.9\%) had colorectal adenocarcinoma and formed the TG. Sixty-five (45.1\%) were taken to be members of the CG.

The groups did not differ significantly according to gender, age and tumor location, thus showing that there was homogeneity between them.

Out of the 41 patients with HPV, 36 (45.6\%) were in the TG and five $(7.7 \%)$ in the CG. Thus, there was a significant difference between the groups (Table 1). The TG had a higher percentage of cases in which the presence of HPV was identified, compared with the CG (chi-square test; $p<0.001$ ).

TABLE 1 - Patients' characteristics according to the presence or absence of DNA of HPV in both study groups

\begin{tabular}{|c|c|c|c|}
\hline \multicolumn{3}{|c|}{ HPV } \\
\hline & TG(\%) & CG(\%) & $p$ \\
\hline Positive & 45,6 & 7,7 & $*$ \\
\hline Negative & 54,4 & 92,3 & ${ }^{*} p<0,001$ \\
\hline Total & 100 & 100 & \\
\hline
\end{tabular}

${ }^{*}$ ) descriptive probability level of the chi-square test

Among the TG cases, there were no significant differences regarding gender, age or location in relation to the presence of HPV. The patients in the TG also did not show any significant difference in relation the stage or the degree of cell differentiation (Table 2).

TABLE 2 - Characteristics of 79 test group patients according to TNM stage, clinical stage and degree of cell differentiation regarding the presence or absence of HPV in absolute numbers and percentages

\begin{tabular}{|c|c|c|c|c|c|c|}
\hline \multirow{3}{*}{ Variable } & \multicolumn{6}{|c|}{ HPV } \\
\hline & \multirow{2}{*}{ Category } & \multicolumn{2}{|c|}{ Positive } & \multicolumn{2}{|c|}{ Negative } & \multirow{2}{*}{$p$} \\
\hline & & $n$ & $\%$ & $\mathrm{n}$ & $\%$ & \\
\hline \multirow{4}{*}{$\begin{array}{c}\text { Degree of } \\
\text { Differentiation }\end{array}$} & I & 4 & 11,1 & 8 & 18,6 & \multirow{4}{*}{$0,269^{(2)}$} \\
\hline & II & 26 & 72,2 & 31 & 72,1 & \\
\hline & III & 3 & 8,3 & 4 & 9,3 & \\
\hline & IV & 3 & 8,3 & 0 & 0,0 & \\
\hline \multirow{4}{*}{ T stage } & 1 & 1 & 2,8 & 1 & 2,3 & \multirow{4}{*}{$0,877^{(2)}$} \\
\hline & 2 & 5 & 13,9 & 8 & 18,6 & \\
\hline & 3 & 27 & 75,0 & 29 & 67,4 & \\
\hline & 4 & 3 & 8,3 & 5 & 11,6 & \\
\hline \multirow{3}{*}{$\mathrm{N}$ stage } & 0 & 17 & 47,2 & 25 & 58,1 & \multirow{3}{*}{$0,613^{(1)}$} \\
\hline & 1 & 11 & 30,6 & 11 & 25,6 & \\
\hline & 2 & 8 & 22,2 & 7 & 16,3 & \\
\hline \multirow{2}{*}{ M stage } & 0 & 28 & 77,8 & 35 & 81,4 & \multirow{2}{*}{$0,690^{(1)}$} \\
\hline & 1 & 8 & 22,2 & 8 & 18,6 & \\
\hline \multirow{2}{*}{ Clinic stage } & I / II & 14 & 38,9 & 23 & 53,5 & \multirow{2}{*}{$0,195^{(1)}$} \\
\hline & III / IV & 22 & 61,1 & 20 & 46,5 & \\
\hline
\end{tabular}

${ }^{(1)}$ descriptive probability level of the chi-square test; ${ }^{(2)}$ descriptive probability level of the Fisher exact test

Regarding the location of HPV in relation to the collection site, no statistically significant difference was observed (Figure 1).

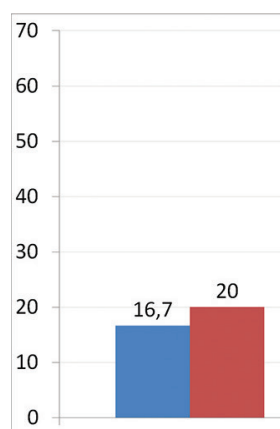

$C D$

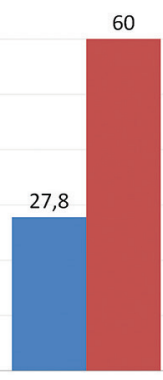

CE $\square \mathrm{GT} \square \mathrm{GC}$

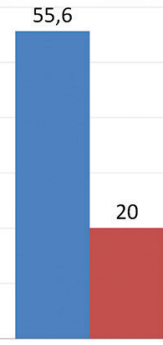

Reto
FIGURE 1 - Distribution of cases in relation to presence of HPV and sample collection site in both groups, represented as percentages (\%)

\section{DISCUSSION}

Knowledge about the cellular and molecular mechanisms relating to colorectal cancer has been improving over recent years. However, even with advances in diagnostic and therapeutic methods such as surgery, chemotherapy and radiotherapy, the five-year survival rate remains around $40 \%{ }^{10}$. When treatment is performed in the early stages, this survival rate can reach $80 \%$, whereas in cases of advanced disease, only $20 \%$ will still be alive after five years ${ }^{17}$.

According to Ponz de Leon $^{20}$, specific etiology has only been established for $3.7 \%$ of colorectal cancer cases. The commonest of these causes is HNPCC, but the etiology remains unclear in the vast majority of the cases (96.3\%).

Based on the literature investigated, it is can be affirmed that about $15 \%$ of neoplasms generally have viral etiology. This cause contributes towards human 
carcinogenesis by favoring genetic instability and inducing chromosomal aberrations ${ }^{7}$.

Based on these data, it can pose questions regarding the possibility that a virus, HPV in this case, might promote changes that could result in development of colorectal cancer. This possibility could favor development of strategies to control this disease, which is responsible for high mortality and morbidity worldwide.

From these data, it is believed that the controversy that exists in the literature regarding the possible association between HPV and colorectal cancer is one of the most important justifications for the present study.

In comparing the two groups, it can be seen that the age variable was not significant, although the age of the patients in the CG was lower than the age in the GT. This was probably due to differences relating to occurrences of the malignant form of the disease, which is more common from the fifth decade of life onwards, thus differing from what is observed among controls, i.e. among individuals who are not cancer patients.

The variables of age, gender, and site involved did not show any differences, thus indicating that the groups were homogeneous.

In analyzing the cancer group regarding the presence or absence of HPV in relation to sex, age, tumor location and other variables associated with the prognosis any differences were found. Other authors have also not observed any differences in these variables ${ }^{2,4,5}$.

In studies that identified the presence of HPV at sites other than the colon, such as in cases of head and neck cancer ${ }^{25}$ and lung cancer $^{6}$, it was observed that when significantly associated with HPV, these cancers were related to a better prognosis. However, these authors did not observe this relationship.

Through analyzing the variable of tumor location, it could be noted that papillomavirus DNA was present in both groups, and was most common in the region of the rectum. It was also found in other regions of the large intestine, but the difference was not significant. This may be related to forms of contamination in this region other than the retrograde pathway from the anogenital region.

PCR on HPV, using paraffin-embedded material, has specificity comparable to in situ hybridization. PCR using specific primers is able to amplify and detect small portions of the HPV genome of up to $119 \mathrm{bp}$, from fragments of HPV type 16 or 18 , which is part of the E6 or E7 gene of HPV ${ }^{23}$

Dot Blot hybridization has been performed in several studies with the aim of detecting human papillomavirus DNA in material extracted by means of a biopsy on the uterine cervix ${ }^{11,16}$. This method has lower sensitivity and specificity than southern blot hybridization, which could explain the variation in the prevalence of HPV around the world, at various sites of the human body, depending on the techniques used for detecting HPV DNA. These variations from the techniques used may be underestimating the true prevalence of $\mathrm{HPV}^{11}$.

Initially in this study, PCR was performed using generic primers for HPV $(\mathrm{GP} 5+/ \mathrm{GP} 6+)^{17}$, which were able to amplify $140 \mathrm{bp}$ of the HPV L1 gene. After this procedure, the samples were subjected to Dot Blot hybridization in order to identify HPV types $6,11,16,18,31,33,34,35,39,40,42,43,44,45$ $51,52,54,56$ and 58 . However, it was only possible to identify HPV 16

From these data, was chosen to perform PCR with specific primers for E7 in HPV 16 and 18, in accordance with the method proposed by Molina (2004) ${ }^{14}$, because other authors have demonstrated the presence of HPV 18 DNA in colorectal cancer samples $2,5,9$

After conducting PCR with specific primers for E7 in HPV 16 and 18, it was not possible to identify HPV 18. These data are consistent with the findings of Weinberger $(2004)^{30}$ who did not make reference in their results to any presence of HPV 18, through using real-time PCR, they only showed HPV 16 and found a significant correlation with patients at an early stage.

On the other hand, Lee ${ }^{9}$ identified the presence of HPV 18 DNA in about $84 \%$ of his samples, through PCR followed by southern blot hybridization for HPV 18 typing. These results were divergent from these data, possibly due to demographic differences, given that in the study by Lee ${ }^{9}$, the population was Asian, whereas here and in Weinberger ${ }^{30}$, it was in a western population.

Bodagui $^{2}$ showed that HPV 18 was present in only $13 \%$ of their samples. They concluded that HPV 16 (82\% of the cases) may be related to development of colorectal cancer and that this would not be originated in the anogenital region, as there was higher incidence in the cecum and ascending colon, in a non significant way.

In previous studies that used detection techniques similar to what here was used, the presence of HPV ranged from $32 \%$ found by McGregor ${ }^{13}$ to $84 \%$ found by Lee ${ }^{9}$. Was observed in this study the presence of HPV 16 in $45.6 \%$ of the samples from patients with colorectal cancer and, in comparing them with the control group, was found a significant difference that may have been related to the development of colorectal cancer.

Unlike other authors, was showed that HPV 16 was present in $7.7 \%$ of the samples from patients in the CG. This may have been related to the tissue collection method, which was from colonoscopies, which could have contaminated the samples with HPV from the anogenital region.

In Brazil, the first study linking the presence of HPV with colorectal cancer was conducted in Rio Grande do Sul by Damin $^{5}$, in which it was observed that $83.3 \%$ of the samples were positive for HPV DNA. Type 16 was the one most commonly found, representing approximately $68.3 \%$ of the cases, but this did not have any relationship with prognostic factors. However, it suggests that HPV may be associated with the pathogenesis of colorectal cancer.

In this study, the prevalence of HPV was $45.6 \%$, unlike the findings of Damin ${ }^{5}$. This variation may have been due to lower incidence of colorectal cancer in state of Pará than in Rio Grande do Sul. Another factor that may have been associated was that in this study, was used material from samples that had been embedded in paraffin for preservation, which is known to lead to the possibility of degradation of the DNA in the samples. This differed from the technique of Damin ${ }^{5}$, who used fresh material obtained during surgery that was preserved in liquid nitrogen.

In this study, was not found any significant association between the presence of HPV and the staging and degree of cell differentiation in patients with HPV, in comparison with cases in which this was not shown by the techniques that here used.

Other authors who investigated this association also failed to demonstrate this association with colorectal cancer, as noted by Cheng ${ }^{4}$. The possibility that the use of archived and paraffin-embedded material may have been responsible for this lack of evidence cannot be ruled out. However, the study by Damin ${ }^{5}$ used fresh material obtained during surgery and was also unable to promote this association.

The findings obtained over the course of this study coincide with data in the literature in which was observed the presence of HPV in tissue samples from patients with colorectal cancer. However, other authors did not identify HPV, and this could be related to the many different techniques for identifying HPV DNA used in these studies.

It is possible to correlate the presence of HPV with colorectal cancer and in case of this study there was a relationship with HPV 16, but not with HPV 18.

Were observed some limitations over the course of this study, but these limitations do not invalidate the results. It 
is believed that these conclusions may provide important contributions towards resolving the controversies that still persist even after the previous studies. Colorectal cancer is a disease of multifactorial origin and the demonstration that HPV is associated with it may favor alternatives for lessening the appearance of colorectal cancer.

Based on these data, was shown the presence of human papillomavirus in individuals with colorectal carcinoma and that this may be associated with cancer development. However, its presence was not related to the stage or degree of cell differentiation in the patients studied.

\section{CONCLUSION}

Human papillomavirus type 16 is present in individuals with colorectal carcinoma. However, its presence was unrelated to staging or degree of differentiation.

\section{ACKNOWLEDGEMENT}

The authors thank in particular to Mrs. Maria Antonieta A. Andreoli, Supervisor of the laboratory of the Ludwig Cancer Research Institute at the Oswaldo Cruz German Hospital for her cooperation in conducting PCR and lessons on technique and procedures.

\section{REFERENCES}

1. Bauer HM, Ting Y, Greer CE, Chambers JC, Tashiro CJ, Chimera J, Reingold A, Manos M. Genital Human papillomavirus infection in female university Students as Determined by a PCR-Based Method. JAMA. 1991; 265: 472-77.

2. Bodaghi S, Yamanegi K, Xiao SY, Da Costa M, Palefsky JM, Zheng ZM. Colorectal papillomavirus infection in patients with colorectal cancer. Clin Cancer Res. 2005; 11(8):2862-7.

3. Buyru N, Tezol A, Dalay N. Coexistence of K-ras mutations and HPV infection in colon cancer. BMC Cancer. 2005; 6:115.

4. Cheng JY, Sheu LF, Lin JC, Meng CL. Detection of human papillomavirus DNA in colorectal adenomas. Arch Surg. 1995; 130: 73-6.

5. Damin DC, Caetano MB, Rosito MA, Schwartsmann G, Damin AS, Frazzon AP, Ruppenthal RD, Alexandre CO. Evidence for an association of human papillomavirus infection and colorectal cancer. Eur J Surg Oncol. 2007; 33(5):569-74.

6. Giuliani L, Jaxmar T, Casadio C, Gariglio M, Manna A, D'Antonio $D$, Syrjanen K, Favalli C, Ciotti M. Detection of oncogenic viruses (SV40, BKV, JCV, HCMV, HPV) and p53 codon 72 polymorprism in lung carcinoma. Lung Cancer. 2007; 57: 273-281.

7. Giuliani L, Ronci C, Bonifacio D, Di Bonito L, Favalli C, Perno CF, Syrjanen K, Ciotti M. Detection of Oncogenic DNA Viruses In Colorectal Cancer. Anticancer Research. 2008; 28: 1405-10.

8. Husman AMR, Walboomers JMM, van den Brule AJC, Meijer CJLM, Snijders PJF. The use of general primers GP5 and GP6 elongated at their 3 ends with adjacent highly conserved sequences improves human papillomavirus detection by PCR. Journal of General Virology. 1995; 76: 1057-62.

9. Lee YM, Leu SY, Chiang H, Fung $C P$, liu WT. Human papilomavírus type 18 in colorectal cancer. J Microbiol Immunol Infect. 2001; 34: 87-91.

10. Leslie A, Carey FA, Pratt NR, Steele RJC. The colorectal adenomacarcinoma sequence. British Journal of Surgery. 2002; 89: 845-60.

11. Low SH, Thong TW, Ho TH, Lee YS, Morita T, Singh M, Yap EH, Chan YC. Prevalence of human papillomavirus types 16 and 18 in cervical carcinomas: a study by Dot and Southern blot hybridization and the polymerase chain reaction. Jpn. J. Cancer Res. 1990; 81: 1118-23.
12. Magi JC, Rodrigues MRS, Guerra GMLSR, Costa MC, Costa ACL, Villa LL, Formiga GJS. Resultados do Exame Anátomo-Patológico e "Polymerase Chain Reaction (PCR)" na Forma Clinica e Subclinica da Infecção Anal pelo Papilomavirus Humano (HPV) - Estudo em Quatro Grupos de Pacientes. Rev bras Coloproct. 2006; 26(4): 406-413.

13. McGregor B, Byrne P, Kirgan D, Albright J, Manalo P, Hall P. Confirmation of the association of human papilomavírus with human colon cancer. The American Journal of Surgery. 1993; 166: 738-42.

14. Molina AL, Tobo PR. Uso das técnicas de biologia molecular para diagnóstico. Einstein. 2004; 2(2): 136-9.

15. Muñoz N. Human papillomavírus and cancer: the epidemiological evidence. Journal of Clinical Virology. 2000; 19: 1-5.

16. Noronha V, Mello W, Villa L, Brito A, Macedo R, Bisi F, Mota R, Sassamoto K, Monteiro T, Linhares A. Papilomavírus associado a lesões de cérvice uterina. Revista da Sociedade Brasileira de Medicina tropical. 1999; 32(3): 235-40.

17. Palma RT, Waisberg J, Simões AB, Bromberg SH, Appolonio F. Significado prognóstico das micrometastases do carcinoma colorretal. Detecção imunoistoquímica com anticorpos anticitoqueratina AE1/AE3. Rev Col Bras Cir. 2002; 29(3): 131-7.

18. Pérez LO, Abba MC, Laguens RM, Golijow CD. Analysis of adenocarcinoma of the colon and rectum: detection of human papillomavirus (HPV) DNA by polymerase chain reaction. Colorectal Disease. 2005; 7(5):492-5.

19. Pinho $M$, Rossi BM. Conceitos atuais sobre carcinogênese colorretal. Rev Bras Coloproct. 1999; 19(1): 57-60.

20. Ponz de Leon $M$, Benatti $P$, Borghi $F$, Pedroni $M$, Scarselli $A$, Di Gregorio C, Losi L, Viel A, Genuardi M, Abbati G, Rossi G, Menigatti M, Lamberti I, Ponti G, Roncucci L. Aetiology of colorectal câncer and relevance of monogenic inheritance. Gut. 2004; 53: 115-122.

21. Prado JC, Calleja-Macias IE, Bernard HU, Kalantari M, Macay SA, Allan B, ET al. Worldwide genomic diversity of the human papilomavírus-53, 56, and 66, a group of high-risk HPVs unrelated to HPV-16 and HPV-18. Virology. 2005; 340: 95-104.

22. Sambrook J, Russel DW. Molecular Cloning. A laboratory manual. Cold Spring Harbor Laboratory Press; 2001.

23. Shibata D, Fu YS, Gupta JW, Shah KV, Arnheim N, Martin WJ. Detection of human papillomavirus in normal and dysplastic tissue by the polymerase chain reaction. Laboratory Investigation. 1988; 59(4): 555-9.

24. Soares PC, Ferreira S, Villa LL, Matos D. Identificação do papilomavírus humano em doentes com carcinoma de células escamosas do canal anal e sua relação com o grau de diferenciação celular e estadiamento. Rev bras coloproct. 2011; 31(1): 8-16.

25. Syrjanen S. Human papillomavirus (HPV) in head and neck cancer. J Clin Virol. 2005; 32S: S59-S66.

26. Villa LL, Franco ELF, Epidemiologic correlates of cervical neoplaisa and risk of human papillomavirus infection in asymptomatic women in Brazil. J Natl Cancer Inst. 1989; 81: 332-40.

27. Villa LL, Sichero $L$, Rahal $P$, Caballero $O$, Ferenczy $A$, Rohan $T$, Franco EL. Molecular variants of human papillomavirus types 16 and 18 preferentially associated with cervical neoplasia. Journal of General Virology. 2000; 81: 2959-68.

28. Vogelstein B, Fearon BA, Hamilton SR, Kern SE, Preisinger AC, Leppert M, Nakamura Y, White R, Smits AMM, Bos JL. Genetic Alterations Colorectal-tumor Development. N Engl J Med. 1988; 319(9): 525-32

29. Yee C, Krishnan-Hewlett I, Baker CC, Schlegel R, Howley PM. Presence and expression of Human papillomavirus sequences in Human Cervical Carcinoma Cell Lines. Am J Pathol. 1985; 119: 361-66.

30. Weinberger PM, Yu Z, Zerkowski M, Chung G, Camp RL, Rimm $\mathrm{DL}$, Psyrri A. A possible association of human papilloma virus with a subset of colorectal adenocarcinomas. Journal of Clinical Oncology Suppl. 2004 (abstract); 22(14s): 3544. 